\title{
PEGylation of therapeutic proteins
}

\begin{tabular}{|r|l|}
\hline Journal: & Biotechnology Journal \\
\hline Manuscript ID: & biot.200900218.R2 \\
\hline Wiley - Manuscript type: & Review \\
\hline Date Submitted by the \\
Author: & $15-$ Nov-2009 \\
\hline Complete List of Authors: & $\begin{array}{l}\text { Jevsevar, Simona; Lek Pharmaceuticals d.d., a Sandoz Company, } \\
\text { Biopharmaceuticals } \\
\text { Kunstelj, Menci; Lek Pharmaceuticals d.d., a Sandoz Company, } \\
\text { Biopharmaceuticals } \\
\text { Gaberc Porekar, Vladka; National Institute of Chemistry }\end{array}$ \\
\hline Main Keywords: & Downstream Processing \\
\hline All Keywords: & Bioseparation \\
\hline Keywords: & $\begin{array}{l}\text { PEGylation, PEGylated therapeutics, analysis, separation, } \\
\text { immunogenicity }\end{array}$ \\
\hline
\end{tabular}

\section{s scholarONE" \\ Manuscript Central}




\section{Abbreviations:}

\begin{tabular}{|l|l|}
\hline AEX & Anion-Exchange Chromatography \\
\hline ANC & absolute neutrophil count \\
\hline CEX & Cation-Exchange Chromatography \\
\hline DBC & Dynamic Binding Capacity \\
\hline DLS & Dynamic light scattering \\
\hline EMEA & European Medicines Evaluation Agency \\
\hline FDA & Food and Drug Administration \\
\hline G-CSF & Granulocyte Colony-Stimulating Factor \\
\hline HES & hydroxyethyl starch \\
\hline hGH & human growth hormone \\
\hline HIC & Hydrophobic Interaction Chromatography \\
\hline IEX & Ion-Exchange Chromatography \\
\hline IFN & Interferon \\
\hline
\end{tabular}




\begin{tabular}{|l|l|}
\hline NHS & N-hydroxy-succinimide ester \\
\hline PD & pharmacodynamic \\
\hline PDGF & Platelet Derived Growth Factor \\
\hline PK & pharmacokinetic \\
\hline RPC & Reversed Phase Chromatography \\
\hline SCID & Severe Combined Immunodeficiency Disease \\
\hline SEC & succinimidyl carbonate PEG \\
\hline SS-PEG & succinimidyl succinate-PEG \\
\hline TNF & Tumor Necrosis Factor \\
\hline VEGFR-2 & vascular endothelial growth factor receptor-2 \\
\hline VHH & variable domain of camelid heavy chain antibody \\
\hline VNAR & variable domain of shark new antigen receptor \\
\hline
\end{tabular}




\begin{abstract}
PEGylation has been widely used as a post-production modification methodology for improving biomedical efficacy and physicochemical properties of therapeutic proteins since, the first PEGylated product was approved by Food and Drug Administration in 1990. Applicability and safety of this technology have been proven by use of various PEGylated pharmaceuticals for many years. It is expected that PEGylation as the most established technology for extension of drug residence in the body will play an important role in the next generation therapeutics, such as peptides, protein nanobodies and scaffolds, which due to their diminished molecular size need half-life extension. This review focuses on several factors important in the production of PEGylated biopharmaceuticals enabling efficient preparation of highly purified PEG-protein conjugates that have to meet stringent regulatory criteria for their use in human therapy. Areas addressed are PEG properties, the specificity of PEGylation reactions, separation and large-scale purification, the availability and analysis of PEG reagents, analysis of PEG-protein conjugates, the consistency of products and processes and approaches used for rapid screening of pharmacokinetic properties of PEG-protein conjugates.
\end{abstract}




\section{Introduction}

Protein and peptide biopharmaceuticals have been successfully used as very efficient drugs in therapy of many pathophysiological states since the first recombinant product insulin was approved in 1982. They became widely available after the rapid development of recombinant DNA technology in the last decades. One group of approved first generation protein biopharmaceuticals mimic native proteins and serve as replacement therapy, while another group represents monoclonal antibodies for antagonist therapy or activating malfunctioning body proteins [1]. The main drawback of the first generation biopharmaceuticals are their suboptimal physicochemical and pharmacokinetic properties. Main limitations are physicochemical instability, limited solubility, proteolytic instability, relatively short elimination half life, immunogenicity and toxicity. Consequently protein therapeutics are mainly administrated parenterally.

Many technologies have been developed in the last decade focusing on improvement of characteristics of the first generation protein drugs to gain the desired pharmacokinetic properties. Half-life extension technologies include amino acid manipulation to reduce immunogenicity and proteolytic instability, genetic fusion to immunoglobulins domains or serum proteins (albumin) and post production modifications - conjugation with natural or synthetic polymers (polysialylation, HESylation and PEGylation).

Additionally, new drug-delivery systems, such as microspheres, liposomes and nano- or micro-particles, are employed to optimize drug properties. It is difficult to judge which of these approaches will most benefit the patient either for short-term or long-term therapy. Amino-acid engineering is the basic strategy, but other approaches, especially fusions and post-production derivatizations or conjugations bring significant elimination half life extension, thus enabling much less frequent administration which is undoubtedly one of the main and the most important benefits for patients. 
The covalent attachment of protein to the polymer polyethylene glycol (PEG) - PEGylation is a well established, widely employed and fast-growing technology that fulfils many of the requirements for safe and efficacious drugs. There have already been several products on the market for a longer time, which proves its efficacy and safety. First attempts to PEGylate proteins occurred in the 1970s, when Abuchowski et. al. [2,3] conducted first conjugations of PEGs to protein and observed improved characteristics of PEG-protein conjugates. The first FDA approved PEGylated biopharmaceutical appeared on the market in 1990 and was a PEGylated form of adenosine deaminase, Adagen ${ }^{\circledR}$ (Enzon Pharmaceuticals, USA), for the treatment of Severe Combined Immunodeficiency Disease (SCID) [4]. Since then, nine different PEGylated products have been FDA approved. Eight of them are PEGylated proteins and one (pegaptanib [Macugen ${ }^{\circledR}$ or Macuverse $\left.{ }^{\circledR}\right]$ ) is a PEGylated anti-Vascular Endothelial Growth Factor (VEGF) aptamer (an RNA oligonucleotide) for the treatment of ocular vascular disease [5]. It is worth-wile to mention that half of these eight approved PEGylated biopharmaceuticals represent blockbuster drugs PegIntron ${ }^{\circledR}$ (Schering-Plough, USA), a PEGylated form of Interferon (IFN) $\alpha-2 b$, Pegasys ${ }^{\circledR}$ (Hoffman-La Roche, Inc., USA), a PEGylated form of IFN $\alpha-2 a$, both for the treatment of hepatitis C; Neulasta® (Amgen, USA), a PEGylated form of Granulocyte Colony-Stimulating Factor (G-CSF) for the treatment of chemotherapy induced neutropenia; and Mircera ${ }^{\circledR}$ (Hoffman-La Roche, Inc., USA), a PEGylated protein (epoietin- $\beta$ ) approved by FDA in 2007 for the treatment of anemia associated with chronic renal failure in adults (but not approved for the treatment of anemia in patients with cancer because of an increased risk for mortality - EMEA product information http://www.emea.europa.eu/humandocs/PDFs/EPAR/mircera/H-739-PI-en.pdf). As an alternative to a full monoclonal antibodies, a PEGylated antibody fragment has already been FDA approved and belongs to the Tumor Necrosis Factor (TNF) inhibitors drug family. 
Cimzia ${ }^{\circledR}$ (UCB Pharma, Belgium), a PEGylated anti-TNF- $\alpha$ Fab' was approved in April 2008 for the treatment of Crohn's disease and in May 2009 for rheumatoid arthritis. The next PEGylated antibody fragment originating from UCB Pharma di-Fab' anti-Platelet Derived Growth Factor (PDGF) (CDP860) [6] is in the advanced stages of clinical trials.

In addition to these already approved PEGylated biopharmaceuticals many more new products can be expected in the near future and are currently in different stages of clinical trials, e.g. BiogenIdec Inc. received in the beginning of July 2009 a Fast Track designation from the FDA for its PEGylated IFN $\beta$-1a for treatment of multiple sclerosis, which means start of a global Phase III study evaluating the efficacy and safety of less frequent administration of $\quad$ PEGylated IFN $\quad \beta-1 \mathrm{a} \quad$ relatively soon (http://www.medicalnewstoday.com/articles/156976.php) [7]. Additionally, an improved version of PEGylated G-CSF (Maxy G34), a site-specifically PEGylated G-CSF analog successfully completed Phase IIa clinical trials (http://www.maxygen.com/productsmye.php). A PEG conjugate of recombinant porcine-like uricase, an enzyme substantially and persistently reducing plasma urate concentrations successfully passed Phase 3 clinical trials [8].

Until now PEGylation has been generated several successful therapeutics available on the market with improved pharmacokinetic behavior and also served as life-cycle management for several proteins resulting in four PEGylated blockbuster drugs [9,10,11]. With further development of scaffolds and nanobodies based biopharmaceuticals increasing number of approved PEGylated drugs can be expected, because PEGylation is the most established technology for extension of drug elimination half-life,

Protein scaffolds represent a new generation of universal binding structure for future biopharmaceutical drug design complementing the existing monoclonal antibodies based therapeutics. Engineered protein scaffolds are generated from small, soluble, stable,

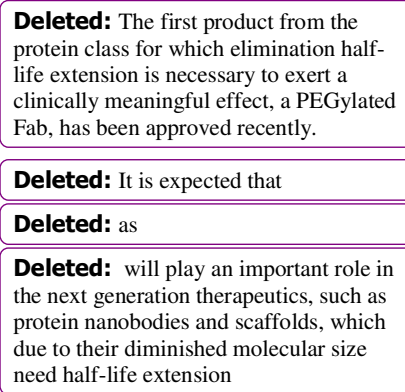

Deleted: will play an important role in the next generation therapeutics, such as protein nanobodies and scaffolds, which due to their diminished molecular size need half-life extension 
monomeric proteins derived from several families such as lipocalins (Anticalin), fibronectin III (AdNectin), Protein A (Affibody), thioredoxin (Peptide aptamer), BPTI/LACI-D1/ITI-D2 (Kunitz domain) and equipped with binding sites for the desired target $[12,13,14]$. Such engineered protein scaffolds are stable, can be overexpressed in microbial expression system and are, due to their small size, efficient in tissue penetration possessing therapeutic potential for intracellular targets in addition to extracellular and cell surface targeting [13]. To prolong their residence time in the body they are often PEGylated. Several protein scaffolds based drugs are in preclinical and clinical trials, including the following PEGylated scaffolds - CT322: Adnectin based antagonist of VEGFR-2 and DX-1000: Kunitz type inhibitor for blocking breast cancer growth and metastasis [12].

Another structure for the development of new generation biopharmaceuticals are nanobodies, single domain antibody fragments devoid of the light chain found in camelids (VHH variable domain of camelid heavy chain antibody) and sharks (VNAR - variable domain of shark new antigen receptor), which are fully functional and capable of binding antigen without domain pairing. The nanobodies are soluble, very stable, do not tend to aggregate and are well overexpressed in microbial expression system making them very attractive for biotechnological and biopharmaceutical applications. An example of successful application of PEGylation to nanobody is PEGylated nanobody neutralizing foot and mouth disease (FMD) virus $₫ 15]$. Several obstacles still have to be circumvented to allow the clinical applications of the nanobodies based therapeutics. With further progress in this field nanobodies based therapeutics can be expected targeting toxins, microbes, viruses, cytokines and tumor antigens $[15,16]$.

Conjugation of PEG to protein results in a new macromolecule with significantly changed physicochemical characteristics. These changes are typically reflected in altered receptor binding affinity, in vitro and in vivo biological activity, absorption rate and bioavailability, 
biodistribution, pharmacokinetic (PK) and pharmacodynamic (PD) profiles, reduced immunogenicity and reduced toxicity. The main drawback of PEGylation is usually reduced biological activity in vitro, which is compensated in vivo by significantly improved pharmacokinetic behavior $[17,18]$. Generally, the longer the PEG chain, the longer the elimination half-life of the PEG-protein conjugate (Fig 1). In addition to PEG length, its shape greatly influences absorption and elimination half-life. Various sources have confirmed that branched PEGs extend elimination half-life more than linear PEGs of the same nominal molecular weight [19].

\section{PEG reagents and their availability}

PEG reagents are commercially available in different lengths, shapes and chemistries allowing them to react with particular functional groups of proteins for their covalent attachment. Commercial suppliers are e.g. NOF Corporation (Japan); SunBio (South Korea); Chirotech Technology Limited (UK), their PEG business was taken over by Dr. Reddys in 2008; JenKem (China); Creative PEGWorks (USA).

PEG is generally regarded as a non-biodegradable polymer, but some reports clearly show that it can be oxidatively degraded by various enzymes, such as alcohol and aldehyde dehydrogenases [20,21] and cytochrome P450-dependent oxidases [22]. PEG chains shorter than $400 \mathrm{Da}$ are in vivo metabolized by alcohol dehydrogenases to toxic metabolites. Longer PEG chains, which are used for PEGylation of proteins, are not subjected to metabolism, and the elimination mechanism depends on their molecular weight. PEG molecules and PEGprotein conjugates with a Mw of PEGs below $20 \mathrm{kDa}$ are eliminated by renal filtration, while protein conjugates with larger PEG molecules are cleared from the body by other pathways, such as liver uptake, via the immune system and proteolytic digestion of the protein part of 
the conjugate. These are also the natural clearing mechanisms for large protein molecules with molecular masses above $70 \mathrm{kDa}$ [23].

PEG has a long history as a non-toxic, nonimmunogenic, hydrophilic, uncharged and nondegradable polymer and has been approved by the US FDA as 'generally recognized as safe' [24]. PEG is typically polydisperse. PEGs and PEG reagents with broad polydispersity were used in the past, whereas nowadays polydispersity indexes of approximately 1.05 are the accepted standard for PEG reagents up to $30 \mathrm{kDa}$ length. For higher Mw, a polidispersity of 1.1 may still be acceptable, however the general trend is directed to PEGs with narrower distributions. Polydispersity of the polymer is one of the factors that aggravate final characterization of PEG-protein conjugates. The current practice employs linear and branched PEGs with molecular masses up to $40 \mathrm{kDa}$, which bring the desired improvement of pharmacokinetic properties, nevertheless new PEG formats such as forked, multi-arm and comb-shaped PEGs show great promises for the future. The macromolecular structure of the conjugating PEG polymer appears crucial for the improved properties of the conjugates. In this sense comb-shaped PEGs bearing numerous short PEG chains attached to the polymer backbone that can be prepared by Transition Metal-Mediated Living Radical Polymerization, offer an additional advantage of relatively tightly controlled polymer molecular weight and architecture [11]. A promising approach represents releasable PEGylation - an attachment of PEG reagent with releasable linker to the protein. This overcomes drug inactivation by conjugation and enables release of the full potency drug, increases solubility of poorly soluble drugs and deposits such drugs at the target, allows random PEGylation and by appropriate selection of the linker also control of PK parameters. At the same time some major benefits of traditional PEGylation are lost, e.g., long elimination half-life, reduced immunogenicity, reduced proteolysis and easier formulation and analytics of stable PEGylated proteins [25]. 
Significantly improved physico-chemical characteristics after coupling of PEG to a protein can be explained by the increased hydrodynamic volume of the PEG-protein conjugate resulting from the ability of PEG to coordinate water molecules and from the high flexibility of the PEG chain. Consequently, apparent Mw of the PEG-protein conjugate is around 5 to 10 fold higher in comparison to the globular protein of the same nominal Mw [26]. PEG chains can sweep around the protein to shield and protect it from the environment (or vice versa), but they also influence the interactions of the protein that are responsible for its biological function. This is considered as the basis for the certain discrepancy between the in vitro and in vivo activities of PEGylated proteins. Generally, the preserved in vitro biological activity after PEGylation is reduced, sometimes very significantly, nevertheless, the in vivo pharmacological effects are usually enhanced. Pegasys ${ }^{\circledR}$, a PEGylated IFN $\alpha-2 a$, is a typical example of a very efficient PEGylated protein drug that displays an in vitro activity of only a few percent of the level of the unmodified IFN $\alpha$, while its efficacy justifies replacement of the first generation IFN $\alpha$ in therapy [27].

\section{Immunogenicity and safety of PEGylated proteins}

PEGylation normally reduces immunogenicity of proteins, there are examples of transforming immunogenic proteins into a tolerogen by PEGylation [28]. Generally, it is often not easy to predict characteristics of PEG-protein conjugates, because they strongly depend on the physicochemical properties of the protein, polymer and final conjugate. The likelihood of an immunogenic reaction of conjugates increases with the level of immunogenicity of the nonmodified protein. A typical example is PEG-uricase, a recombinant enzyme capable of degrading high levels of uric acid in patients with hyperuricemia. Unlike most mammals, humans lack an uricase enzyme, therefore for therapeutic purposes an enzyme totally foreign to the human body (porcine-like) is used which has to be sufficiently PEGylated to mask its 
immunogenicity [8]. However, during Phase 1 clinical trials the formation of unusual antiPEG antibodies was detected in some patients [29]. Presumably the methoxyl group in the PEG chain at the terminus remote from the linker to the protein [8, WO 2004/030617 A2] was identified as a source of antigenicity, which is rather surprising since methoxyl end-capped PEGs are generally used in modern marketed PEGylated biopharmaceuticals without reports on PEG immunogenicity. However, a few reports on induction of anti-PEG immune responses in the case of repeated administration of PEGylated liposomes [30,31] or PEGglucuronidase can be found in literature [32]. High levels of PEG used as an intravenous therapeutic agent "per se" have been shown to generate concentration and molecular mass dependent serum complement activation [33], however the quantities of PEG administered in PEGylated therapeutics are 10000 to 1000 -fold lower. In toxicology studies very high doses of PEG-protein conjugates have been demonstrated as capable of inducing renal tubular vacuolization, not associated with functional abnormalities that disappears after the treatment [34]. Therefore PEG-protein conjugates remain regarded as immunologically safe and nontoxic. It has also been demonstrated that potential protein immunogenicity can be better alleviated by attachment of larger and branched PEGs than by shorter and linear PEGs. In general, low immunogenicity of PEG and relatively low dosages of PEG-conjugates reduce the risk for an immunogenic response significantly $[23,35,36,37,38]$.

Conjugation might sometimes lead to formation of new epitopes as a consequence, e. g. of partial protein denaturation after conjugation or use of an inappropriate spacer between protein and PEG chain. Hence it is important to pay attention to suitable PEGylation chemistry, solution conditions and careful selection of the PEGylation site [37].

The size and shape of the PEG-protein conjugates determines their distribution and accumulation in the liver and other organs that are rich in reticuloendothelial cells, such as the spleen, lymph nodes, lungs and kidneys. Clearance from these organs is lower for PEG- 
protein conjugates than for native or glycosylated proteins. Severe side effects have not been reported, but consequences of lifelong therapies with high dosages of PEG-protein conjugates containing PEG conjugates with high molecular masses are hardly predictable. Occasional warnings that significant PEG-protein accumulation in the liver may increase the risk of toxicity have appeared $[23,39,40]$.

\section{PEGylation reaction/chemistry}

PEGylation of proteins is usually achieved by a chemical reaction between the protein and suitably activated PEGylation reagents. There are various chemical groups in the amino acid side chains that could in principle be exploited for the reaction with PEG moiety, such as $\mathrm{NH} 2$, -NH-, - $\mathrm{COOH},-\mathrm{OH},-\mathrm{SH}$ groups as well as disulfide (-S-S-) bonds. However, not only the protein attachment site for the PEGylation reagent is important. When speaking about PEGylation and PEGylated proteins, respectively, especially about their altered properties, various aspects of the process have to be considered, such as the attachment site on the protein, activation type of the PEG reagent, nature (permanent or cleavable), length and shape of the linker, length, shape and structure of the PEG reagent as well as end capping of the PEG chains.

\section{Random PEGylation}

When looking back into the history of PEGylation it can be seen that until recently, the majority of the PEGylation reagents developed targeted amino groups on the protein, most frequently the $\varepsilon$-amino groups on the side chains of lysine residues. Lysines are polar and relatively abundant amino acid residues usually located on the protein surface, which make them prone to chemical reactions with PEG reagents. Consequently such reactions advance quickly and lead to complex mixtures of conjugates, differing in the number and site of the 
attached PEG chains. In addition, most of the PEGylation reagents employed are not strongly specific for the reaction with the amino groups of the lysine residues but react to a minor degree also with other protein nucleophiles: $N$-terminal amino groups, the imidazolyl nitrogens of histidine residues and even with the side chains of serine, threonine, tyrosine and cysteine residues. Although the reaction can be directed to some extent by the $\mathrm{pH}$ of the medium (for the reaction to proceed, the nucleophil must always be in the non-protonated form), this type of conjugation reactions always lead to complex PEGylation mixtures. The historical development of such "random" PEGylation reagents began in the 1970s with PEGchlorotriazine reagents [2,3] and continued with succinimidyl succinate (SS-PEG) [41] and succinimidyl carbonate PEG reagents (SC-PEGs) $[42,43]$. SS-PEG reagents produce stable amide bonds (-CO-NH-Protein) with the protein but due to another ester linkage in the polymer backbone the resulting PEG-protein conjugates are susceptible to hydrolysis. SCPEG reagents form urethane linkages (-O-CO-NH-Protein) and react, beside with lysine residues, also with histidine residues resulting in hydrolytically unstable linkages. The weak linkage could be used to advantage in preparation of controlled-release or pro-drug formulations, as in the case of PegIntron ${ }^{\circledR}$, or it could be a severe disadvantage if the conjugate instability was not desired. Although numerous other chemistries have also been tried in the past, most of the random PEGylation reagents possess the activated carbonyl group in the form of N-hydroxy-succinimide esters (NHS) that form stable protein-PEG conjugates via amide linkages. Depending on the reaction conditions (reaction time, temperature, $\mathrm{pH}$, amount of PEG reagent and protein concentration), mono-, di-, tri- and numerous higher-PEGylated conjugates can be formed. However, due to reactions with different nucleophilic groups on the protein, even mono-PEGylation leads to positional isomers that can differ substantially in their biological and biomedical properties. 
The first PEGylated pharmaceuticals Adagen ${ }^{\circledR}$ (pegademase) and Oncaspar ${ }^{\circledR}$ (PEGylated asparaginase, pegaspargase) were actually complex mixtures of various PEGylated species. Pegademase has been proven to be much more efficient than the partial exchange transfusions of red blood cells that represented the standard therapy before approval of pegademase. Pegaspargase serves for treatment of various leukaemias and has addressed the problem of neutralizing antibodies associated with the use of native asparaginase.

However, also later on approved drugs, PegIntron ${ }^{\circledR}$ and Pegasys ${ }^{\circledR}$, are produced by random PEGylation. Both biopharmaceutical drugs are mixtures of mono-PEGylated positional isomers, containing linear $12 \mathrm{kDa}$ PEG chains bound to different sites of IFN- $\alpha 2 \mathrm{~b}$ in the case of PegIntron ${ }^{\circledR}$, (http://www.emea.europa.eu/humandocs/PDFs/EPAR/Pegintron/024400en6.pdf) and branched $40 \mathrm{kDa}$ PEG chains bound mainly to four Lys residues of IFN- $\alpha 2 \mathrm{a}$ in the case of

Pegasys ${ }^{\circledR}$, (http://www.emea.europa.eu/humandocs/PDFs/EPAR/pegasys/199602en6.pdf). Another interesting PEGylated biopharmaceutical drug, produced by random PEGylation, is pegvisomant (Somavert $\AA$, Pfizer) that was approved in 2003 for the treatment of acromegaly. Pegvisomant has been designed to function as an antagonist of the hGH receptor (HGHR) by substitution of certain amino acids in the backbone of the protein hGH. Modifications include several mutations on the protein and conjugation with 4-6 $5 \mathrm{kDa}$ PEG chains per molecule (http://www.emea.europa.eu/humandocs/PDFs/EPAR/somavert/486302en6.pdf).

Even Mircera®, that was FDA approved in 2007, is a mixture of mono-PEGylated conjugates of erithropoietin, with a $30 \mathrm{kDa}$ PEG attached either to lysine residues (mostly Lys52 and Lys45) or the protein $\mathrm{N}$-terminus, (http://www.emea.europa.eu/humandocs/PDFs/EPAR/mircera/H-739-en6.pdf).
Deleted: Both Enzon products were launched in the early nineties.

Deleted: that were brought to the market in 2001 and 2002, respectively,

Deleted: Both PEGylated pharmaceuticals have substantially longer elimination half-lives than the unPEGylated IFN- $\alpha$ drug Intron $A \circledR$, which enables one per week applications and more efficient anti-virus therapy. 
Although purification would allow homogenous product preparation, one of the obvious trends in the development of the PEGylation technology is a shift from random to site-specific PEGylation reactions, leading to better defined products. Examples of classical, well-known approaches toward site-specific PEGylation reactions are $N$-terminal and cysteine-specific PEGylations.

$N$-terminal PEGylation, performed as a reductive alkylation step with a PEG-aldehyde reagent and a reducing agent (e.g., sodium cianoborohydride) [44], was employed in the development of Neulasta ${ }^{\circledR}$ [45], which is an $N$-terminally mono-PEGylated G-CSF bearing a $20 \mathrm{kDa}$ PEG, (EMEA product information -

http://www.emea.europa.eu/humandocs/PDFs/EPAR/neulasta/296102en6.pdf). The improved pharmacokinetic behavior enables administration only once per each chemotherapy cycle compared to the first generation, Neupogen ${ }^{2}$, which is administered daily (up to two weeks in each chemotherapy cycle),

PEGylation of thiol groups in natural or genetically introduced unpaired cysteines is another well-known approach to site-specific PEGylation. A variety of thiol-specific reagents are available, such as maleimide, pyridyl disulfide, vinyl sulfone, thiol reagents, etc. Due to the stability of the formed linkages, maleimide-PEG reagents have become very popular. In native proteins, cysteine residues are usually involved in disulfide bridges or responsible for interaction with metals or other proteins, but a good example of single cysteine PEGylation of G-CSF has been described. To achieve site-specific PEGylation of the unpaired Cys18 which is only partially exposed, the PEGylation was performed under transient denaturating conditions [46]. Genetically introduced cysteines represent an opportunity to direct the PEG moiety to an exactly determined site in the molecule. In the case of IFN- $\alpha 2 a$, several cysteine analogues with high preserved in vitro activity were identified and used for specific PEGylations [47,48]. Another very promising group of proteins for cysteine-specific

Deleted: PEGylated drug is used for the
same purpose as the non-PEGylated first
generation parent drug Neupogen ${ }^{\circledR}$
(Amgen, USA), namely in the treatment
and prevention of neutropenic states,
usually those induced by chemotherapy in
cancer patients. However, the dosage
regimes of these two drugs are essentially
different:

Deleted: PEGylated drug is used for the generation parent drug Neupogen ${ }^{\circledR}$ and prevention), namely in the treatm usually those induced by chemotherapy in . However, the dosage different:

Deleted: until the absolute neutrophil each chemotherapy cycle 
PEGylations are Fab' fragments. PEGylation appears an ideal method to reduce their antigenicity and prolong the in vivo circulation times. However the main benefit of using PEGylated Fab's instead of full antibodies can be elimination of undesired side effects originating from Fc region. Cysteine residues in the hinge region of Fab' fragments that are far from the antigen-binding region, offer the possibility of specific conjugation leading to a well defined product. The most prominent example of this strategy is Cimziaß, a PEGylated Fab' fragment of a humanized anti-TNF- $\alpha$ monoclonal antibody bearing a $40 \mathrm{kDa}$ branched PEG site-specifically attached to a hinge cysteine. Recently it has also been shown that the PEGylation efficiency of Fab' fragments can be substantially increased by exploitation of interchain disulfide bond after its reduction for PEGylation. The final Fab'-PEG product does

Deleted: engineering the Deleted: fragments in such a way that $\mathrm{t}$ not retain the interchain disulfide bond. Such molecules, although without covalent linkage between both antibody chains, retain very high levels of chemical and thermal stability and normal performance in PK and efficacy models [49].

A novel approach to the PEGylation of protein disulfide bonds TheraPEG ${ }^{\mathrm{TM}}$ is a PEGylation Technology of PolyTherics using special PEG monosulfone reagents. The site-specific bisalkylation of both sulfur atoms in the natural disulfide bond that is sufficiently exposed on the protein surface results into the insertion of the PEG linker into the disulfide bond and formation of a three-carbon PEGylated bridge [50,51]. The strategy is appropriate for specific PEGylation of Fab' fragments and will presumably be used for the production of a novel type of PEGylated IFN- $\alpha$ (http://www.chime.plc.uk/press-releases/de-facto-appointed-bypolytherics).

New approach to PEGylation using histidine affinity tags as targets for PEG attachment has been recently published by PolyTherics (WO 2009/047500 A1). Taking into account that histidine affinity tags are among the most frequently used tools for easy and rapid purification of recombinant proteins the strategy appears to offer a certain potential. 
PEGylation via non-natural amino acids requires the genetic manipulation of the protein and of the host organism to allow incorporation of non-natural amino acids (so called Amber technology), which can be specifically conjugated with appropriate PEG reagents.

Following triazole formation by the [3+2] cycloaddition of an alkyne and an azide for selective conjugation, azido and ethynyl derivatives of serine are interesting as they are capable of reacting specifically with matching ethynyl-PEG or azido-PEG reagents [52].

Through the Amber technology approach, company Ambrx generated site specific monoPEGylated hGH molecules with improved pharmacological properties. Phase I/II clinical trial data demonstrated that the long-acting human growth hormone $(\mathrm{hGH})$ analogue developed in collaboration between Ambrx and Merck Serono, normalized insulin-like growth factor I (IGF-I) levels and showed an acceptable safety and tolerability profile in adults with Growth Hormone deficiency (http://www.ambrx.com/wt/page/pr_1226513229). In the Ambrx pipeline more long acting therapeutics can be found (e.g., IFN- $\beta$, FGF21, Leptine), all still in preclinical trials.

Instead of traditional conjugation reactions performed by chemical procedures, enzymes can also be employed to achieve specific PEGylation. Thus, transglutaminase is capable of catalyzing the incorporation of PEG-alkylamine reagents into the protein glutamine residues, which can be either natural or genetically introduced [53]. The reaction offers high degree of specificity since only those glutamine residues that are encompassed in a flexible or unfolded region are modified [54]. Even more promising appears a two-enzyme step GlycoPEGylation $^{\mathrm{TM}}$ technology developed by Neose Technologies Inc, allowing the introduction of PEG chains at natural $O$-glycosylation sites [55]. Starting materials are nonglycosylated recombinant polypeptides obtained by Escherichia coli production systems. Proteins must contain a single $O$-glycosylation site in which a serine or threonine residue functions as an acceptor for selective addition of N-acetylgalactosamine (GalNAc) by the 
recombinant enzyme O-GalNAC-transferase. In the next step the glycosylated protein is PEGylated on O-GalNAC by a cytidine monophosphate derivative of sialic acid-PEG using another recombinant enzyme sialyltransferase. The technology has been tested so far on various pharmaceutically relevant proteins, including G-CSF. GlycoPEG-G-CSF is currently in the most advanced phase of clinical trials (http://www.medicalnewstoday.com/articles/112612.php).

A short overview of PEGylation technologies used today is summarized in Table 1.

\section{Purification of PEGylated proteins}

Purification of PEGylated proteins is required to obtain the final product from the complexity of PEGylation mixtures. The target PEG-protein conjugate has to be separated from unreacted protein, over-PEGylated proteins, unreacted PEG reagent and from other reagents eventually added to the PEGylation mixture. For isolation of the target PEG-protein, differences in charge, hydrodynamic radius, hydrophobicity and in some cases also affinity are exploited [56]. Efficiency of the purification process that results in desired product homogeniecity tipically depends on the complexity of the PEGylation mixture.

Historically, Size-Exclusion Chromatography (SEC) has been widely used for separation of PEG conjugates as increase of molecular weight is one of the most evident changes caused by PEGylation. SEC is very efficient in removing low molecular impurities (by-products formed by hydrolysis of functionalized PEG and other low molecular mass reagents) as well as unreacted protein. SEC has several limitations, which are inability to separate positional isomers of the same molecular weight, poor resolution for PEG-protein conjugates, low throughput and high costs. Using only SEC, even unreacted PEG cannot always be efficiently removed. The removal depends on the molecular size difference between the PEG reagent and 
A difference in hydrodynamic radius larger than 1.26 enables efficient separation [56]. Applying only one SEC step in large-scale production would not result in a product with sufficient purity, therefore SEC is usually used in combination with Hydrophobic Interaction Chromatography (HIC), or with Cation-Exchange Chromatography (CEX) [56].

Hydrophobic Interaction Chromatography (HIC) can also be applied for purification and isolation of PEGylated proteins, although it is not widely used. The main reasons are poor resolution of PEGylated species and binding of unreacted PEG reagent to the HIC columns. The elution of PEGylation mixture components depends on the degree of protein modification. Unmodified protein is eluted first, followed by monoPEGylated and higher PEGylated conjugates [56]. However, higher PEGylated species are usually not well resolved. The removal of unreacted PEG from the target PEG-protein conjugate is not always predictable and depends on the size difference and hydrophobicity of the protein. Generally the method of choice for isolation of PEGylated proteins is Cation-Exchange Chromatography (CEX). CEX enables a single-step purification of the target PEG-protein 
conjugate from un-PEGylated protein, higher PEGylated molecules and unreacted PEG. Due to charge differences, CEX also possesses the ability to separate positional isomers of the same molecular weight. The elution order of PEG-protein conjugates is determined by the PEG to protein mass ratio [59,60]. Higher-PEGylated molecules elute first, followed by mono-PEGylated and unreacted protein. Fig 3 shows efficient CEX separation of higher-, mono-PEGylated and un-PEGylated protein. Additionally retention times on CEX also depend on Mw of PEG attached to the protein. This is also illustrated in Fig 3, where separations of PEGylation mixtures prepared with PEGs of different sizes have been performed under the same conditions. It is seen that conjugates with PEGs of higher Mw exhibit lower retention times. The same elution order as in CEX is also obtained with AnionExchange Chromatography (AEX). PEGylated proteins posses a lower average surface charge, either positive or negative, due to PEG shielding of the protein surface. Reduced interactions between the PEG-protein and the chromatographic resin cause elution of PEGprotein conjugates before un-PEGylated protein in CEX as well as in AEX. The PEG shielding effect is so pronounced, that CEX separation can also be applied in the case where there is no charge difference between PEGylated and un-PEGylated protein $[56,57,60,62]$. PEGylation reactions are usually performed with excess of PEG reagent and at high protein concentrations. All these factors combined with large hydrodynamic radius of PEGs make PEGylation mixtures very viscous. High viscosity and PEG's tendency of absorbing nonspecifically onto the surfaces are two major reasons for causing problems during CEX purification. High back-pressure and column fouling can be avoided by dilution of PEGylation mixtures before loading on to the CEX column. Unreacted PEG reagent does not bind to the CEX resin and elutes in the flow through. The presence of PEG reagent in the load reduces CEX resolution, therefore it is recommended to remove unreacted PEG as soon as possible in the purification process [56]. To achieve efficient removal of PEG reagent and 
efficient separation two consecutive ion exchange (IEX) separations can be performed, the first for removal of unreacted PEG and the second for fractionation of PEG-protein conjugates $[63,64]$. In the first separation step, resins with high porosity and larger particles can be used allowing higher flow rates and higher viscosity of the loaded sample, while for the second step resins with good resolution are recommended.

Increased hydrodynamic radius and masking of the protein surface by PEG are two characteristics that tend to denote CEX purification. PEGylated proteins are associated with lower equilibrium and dynamic binding capacities. Equilibrium binding capacity is reduced as the consequence of weaker interactions between the protein and the resin, caused by PEG shielding, while Dynamic Binding Capacity (DBC) is reduced due to slower mass transfer and hindered diffusion effect associated with molecules of large hydrodynamic radius. Compared to un-PEGylated proteins the DBC for PEGylated proteins is on average 10 times lower [65].. Some producers offer resins specially designed for separation of PEGylated proteins, (http://www6.gelifesciences.com/aptrix/upp00919.nsf/Content/5E17BDCA59B77FC3C12571 8600812910/\$file/28409465AA.pdf).

For a proper choice of the IEX resin special attention has to be paid to the appropriate particle pore size enabling penetration of the PEGylated proteins. In an interesting study, a couple of industrial scale AEX resins were compared. Some resins maintained some DBC after PEGylation, while for few a complete loss of DBC was observed. The loss of DBC after PEGylation was explained by PEG-protein inability to penetrate into the particle pores [65]. An important non-chromatographic step in the production of pharmaceutical proteins is also the Ultrafiltration/Diafiltration (UF/DF) unit operation. The UF/DF process step enables buffer exchange in between the chromatographic steps or into the final drug substance buffer, allowing concentration of the drug substance to the desired final concentration. Since PEGylated proteins are frequently administrated at relatively high concentrations, usually 
around $10 \mathrm{mg} / \mathrm{ml}$, UF/DF is a well-suited final processing step. As the PEG attachment significantly increases the hydrodynamic radius it is thus expected that larger cut-offs of the membranes could be employed. Surprisingly, similar cut-offs as used for un-PEGylated protein should be employed after PEGylation with linear PEG reagents in order to avoid the so called "snake effect" of PEGs, whereby PEGylated product can escape through larger pore membranes causing substantial losses $[58,66,67]$. In the case of branched PEG, and for multiPEGylated conjugates larger cut-offs can be successfully used. However it should be noted that the difference in sieving coefficients is not proportional to the difference in $\mathrm{Mw}$ of conjugated and unconjugated protein.

\section{Analytics of PEG reagents and PEGylated proteins}

The development of an efficient PEGylation process and safe PEGylated therapeutic require analytical methods for PEG-protein conjugates and PEG reagent at various stages.

PEG reagents represent a crucial raw material, therefore their full characterization ability is essential for successful development of PEGylated therapeutics. The quality of PEG reagents may vary substantially with regards to the molecular mass, polydispersity index, presence of activated and non-activated impurities and degree of activation.

Terminal activity or degree of activation, with typical values of 70 to $90 \%$ is a very important characteristic of PEG reagents influencing directly the efficiency of the PEGylation reaction process that may result in different PEG excess needed for the same conversion yield. As PEG reagents contribute a substantial part to the manufacturing costs of PEGylated proteins, a high degree of reagent activation, as well as the ability to control the activation efficiency, play a very important role in the production process of PEGylated proteins. NMR is frequently used for a qualitative and quantitative determination of the functional groups, and can be found as release method for terminal activity determination of all manufacturers of 
activated PEGs. Alternatively, HPLC methods combined with derivatization of the terminal group can be employed effectively. PEG itself, and a majority of PEG reagents, are UV transparent and nonfluorescent, therefore a derivatization method is needed to produce UV absorbance. For example, methoxy-PEG aldehyde can be derivatized with 4-aminobenzoic acid and analyzed using reverse phase (RP)-HPLC [60]. Such an alternative method is very powerful in detecting activated impurities in PEG reagent, which should be kept at a very low level to avoid formation of undesired by-products.

Without derivatization, PEG reagents can be detected with evaporative light scattering or corona discharge charged aerosol detectors that detect particulate matter in the gas phase [68]. RPC and SEC in combination with corona detection mode can be employed for determination of difference in Mw of PEG chains and thus enable detection of impurities in final PEG reagent, however it doesn't have a power to distinguish between activated and non-activated PEG species.

Another characteristic of PEG which has to be well controlled is Mw as it determines the final half-life of the PEGylated protein and directly influences the bioavailability of the PEGylated therapeutics. The average molecular weight of the PEG reagent is usually controlled by SEC. The same method is used for polydispersity determination and determination of the main peak fraction in PEGs. However, a more precise determination of Mw of PEGs is possible by the MALDI-TOF technique. This technique is more complicated and expensive, and although not in routine use yet [69], it will most probably become a standard technique in the production of modern biopharmaceuticals soon.

In the production process of PEGylated therapeutics, full characterization of the PEG-protein conjugates represents a very challenging task. It starts with analysis of PEGylation reaction mixtures, analysis of individual fractions during purification and complete characterization of 
the final product. The characterization of PEGylated proteins is influenced by the fact that the PEG molecule attached to the protein changes the characteristics of the protein substantially. As previously mentioned, the most evident changes caused by PEGylation are a larger size of the molecule and a larger hydrodynamic volume, respectively. Molecular weight of proteins and PEG-protein conjugates can be determined by several methods, such as size exclusion chromatography (SEC), electrophoretic methods, light scattering and mass spectrometry. Most comprehensive studies on PEG-protein conjugate sizes are based on SEC data [58,70]. SEC is a simple and low-cost method of choice enabling molecular weight determination of proteins and polymers on the basis of calibration curves. For analytical purposes addition of organic modifiers into the mobile phase can improve separation of PEG-protein conjugates and reduce peak broadening caused by the polydispersity of PEG as well as peak tailing caused as consequence of non-specific adhesion of PEGs to the stationary phase $[63,71,72]$. Comparison of behavior of PEG reagents, PEG-protein conjugates and proteins of approximately the same nominal molecular weight on SEC and SDS-PAGE show distinctly different retention times (Fig 2) and mobility in gel, $40 \mathrm{kDa}$ PEG reagent behaving as the biggest molecule and protein without conjugation as the smallest. PEGs as well as PEGprotein conjugates are in complete disagreement with protein molecular weight standard [57]. PEG standards seem to be more adequate for a rough estimation of the apparent molecular weight of PEG-protein conjugates than protein standards [70,73].

Dynamic light scattering (DLS) can also be applied for molecular size evaluation of the conjugates. In contrast to SEC it seems to be able to distinguish between protein conjugates with branched and linear PEGs detecting the size of conjugates with branched PEGs smaller than the size of conjugates with linear PEGs of the same nominal molecular weight $[57,61]$. None of the before mentioned methods is able to resolve and detect PEG positional isomers; however CEX is efficient in their separation. By employing CEX it was demonstrated that the 
marketed product PegIntron®, randomly conjugated with a 12-kDa linear PEG, contains 15 different PEG positional isoforms [74] while Pegasys ${ }^{\circledR}$, randomly conjugated with a 40-kDa branched PEG, contains four main isoforms [27]. CEX is also capable of separating different molecular weights in a series of well-defined N-terminally monoPEGylated proteins conjugated with PEGs of different length. The PEG size affects the retention time, which is another indication for PEG's strong shielding and/or steric effect resulting in weakening of the interaction between the protein and the chromatographic matrix [57].

Theoretically, efficient separation of positional isomers could be expected in Reversed Phase Chromatography (RPC), as the method exploits the differences in hydrophobicity. However, positional isomers are not resolved in practice and the PEG-to-protein ratio appears to be the predominant factor that determines the resolution [60]. Based on the fact that PEG is usually regarded as a hydrophilic molecule, PEGylated proteins should exhibit shorter retention times on RPC than their un-PEGylated counterparts, while the opposite is observed. PEGylated proteins show distinctly longer retention times on RPC columns which increase with increasing PEG length exhibiting somehow the hydrophobic nature of PEG. This is also the reason why PEGs themselves are retained and can be separated on RP matrices. RPC is an excellent and robust method for determination of purity and content of PEGylated proteins, including the amount of higher-PEGylated and un-PEGylated species, protein oxidation, deamidation and cleavage of the protein backbone [72] as well as for RP-HPLC peptide mapping [44,63].

Various modes of mass spectroscopy nowadays represent valuable and generally applied tools for protein characterization [75]. The high intensity of PEG-related signals hinders the detection of PEGylated peptides and their fragmentation analysis which can lead to ambiguous identification of PEGylated proteins because the signals and their intensities in Mass Spectrometry (MS) spectra depend on the intrinsic properties of the peptide. 
Nevertheless peptide mapping and MS are used for identification and quantification of PEGylation sites by comparing PEGylated and un-PEGylated counterparts [61,76], as well as for characterization of impurities which may sometimes not be resolved and detected by simpler techniques. However, in the case of monodisperse PEG reagents a direct identification of the PEGylation site(s) is possible using electrospray ionization mass spectrometry (ESI-MS) [77].

\section{Determination of Pharmacokinetic (PK) profiles of PEG-protein conjugates}

The modulation of protein PK characteristics focused on elimination half life extension is the main driver for protein modification, including PEGylation. A first screen of PK properties is usually performed in rodents, most frequently rats which are large enough to allow time course sampling required for PK profile determination. To estimate the concentration to time course of the PEG-protein conjugate in the blood sera with satisfactory sensitivity, specificity, reproducibility and accuracy an universal analytical method for detecting the conjugate in complex biological samples is desired (http://www.emea.europa.eu/pdfs/human/ewp/8924904enfin.pdf). Immunoassays, bioassays and radioassays are frequently used [78], while a more universal antiPEG ELISA test has been developed and offered recently by Epitomics (USA) (http://www.epitomics.com/Kits/ELISA_PEG.php). Although it seems to be a universal and very elegant solution, its applicability in practice is limited due to the relatively high detection limit. Its sensitivity is usually satisfactory for multi-PEGylated conjugates, but it is often not sensitive enough for determination of lower amounts of mono-PEGylated conjugates in blood sera (“our unpublished results"). Most of the marketed PEGylated therapeutics are monoPEGylated and it is not expected that this will change in the future. 
Hence the method of choice is still a protein-specific ELISA, (Enzyme-Linked ImmunoSorbent Assay), usually commercially available with antibodies directed to the protein that is conjugated. The main drawbacks of such ELISA's are their ability to recognize only the protein part, and therefore, lower sensitivity for the PEGylated protein compared to the un-PEGylated counterpart. Lower sensitivity is a consequence of the shielding effect of PEGs that frequently masks amino acid sites important for the receptor binding resulting in weaker interaction with receptor as well as with the target antibodies. Generally, larger PEGs and multi-PEGs attached to protein reduce the affinity for the antibody resulting in the reduced steepness of the dose-response curves. To avoid inaccuracy of the determined concentration of PEG-protein conjugates it is important to use the same purified PEGconjugate for the standard curve. The final concentrations of PEG-conjugates in blood sera should thus be calculated using the standard curve derived from purified PEG-conjugate, and should not be compared to the un-PEGylated protein.

However, in the production of PEGylated therapeutics highly sensitive and specific ELISA methods using anti-PEG capture antibodies and detection antibodies for the respective protein part of the conjugate are now routinely used in $\mathrm{PK}$ studies, and in the determination of drug concentrations in body fluids and in tissue extracts [71, unpublished results]. Most of these methods are proprietary and not available in the public domain.

\section{Conclusions}

In this review numerous aspects of PEGylation technologies have been covered, comprising PEG reagents, their development and novel trends as well as their analysis, PEGylation reactions and large-scale purifications, as well as the analysis of the PEG-protein conjugates. PEGylation is a mature and tested technology, which has already resulted in nine FDA approved therapeutics, testifying the safety and applicability of the methodology. Since its 
introduction PEGylation has been focused more on existing therapeutic proteins and their lifecycle management. However with the development of protein nanobodies [79] and scaffolds [12] which are believed to be the next generation therapeutics but require half-life extension to exert a clinically meaningful effect, even wider medical use can be expected. However, a very complex Intellectual Property (IP) situation exists covering site-specific PEGylation and branched PEG reagents hindering the wider use of modern PEGylation technologies for new products. Expiry of these patents will enable freedom to operate for modern PEGylation technology in the near future and may result in expansion of its use in production of new therapeutics. 


\section{References}

[1] Szymkowski, D. E., Creating the next generation of protein therapeutics through rational drug design. Curr. Opin. Drug Discov. Devel. 2005, 8, 590-600.

[2] Abuchowski, A., Vanes, T., Palczuk, N. C., Davis, F. F., Alteration of Immunological Properties of Bovine Serum-Albumin by Covalent Attachment of Polyethylene-Glycol. J. Biol. Chem. 1977, 252, 3578-3581.

[3] Abuchowski, A., Mccoy, J. R., Palczuk, N. C., Vanes, T. et al., Effect of Covalent Attachment of Polyethylene-Glycol on Immunogenicity and Circulating Life of Bovine Liver Catalase. J. Biol. Chem. 1977, 252, 3582-3586.

[4] Levy, Y., Hershfield, M. S., Fernandez-Mejia, C., Polmar, S. H. et al., Adenosine deaminase deficiency with late onset of recurrent infections: response to treatment with polyethylene glycol-modified adenosine deaminase. J. Pediatr. 1988, 113, 312-317.

[5] Ng, E. W., Shima, D. T., Calias, P., Cunningham, E. T., Jr. et al., Pegaptanib, a targeted anti-VEGF aptamer for ocular vascular disease. Nat. Rev. Drug Discov. 2006, 5, $123-132$.

[6] Serruys, P. W., Heyndrickx, G. R., Patel, J., Cummins, P. A. et al., Effect of an antiPDGF-beta-receptor-blocking antibody on restenosis in patients undergoing elective stent placement. Int. J. Cardiovasc. Intervent. 2003, 5, 214-222.

[7] Baker, D. P., Lin, E. Y., Lin, K., Pellegrini, M. et al., N-terminally PEGylated human interferon-beta-1a with improved pharmacokinetic properties and in vivo efficacy in a melanoma angiogenesis model. Bioconjug. Chem. 2006, 17, 179-188. 
[8] Sherman, M. R., Saifer, M. G., Perez-Ruiz, F., PEG-uricase in the management of treatment-resistant gout and hyperuricemia. Adv. Drug Deliv. Rev. 2008, 60, 59-68.

[9] Bailon, P., Won, C. Y., PEG-modified biopharmaceuticals. Expert. Opin. Drug Deliv. 2009, 6, 1-16.

[10] Kang, J. S., DeLuca, P. P., Lee, K. C., Emerging PEGylated drugs. Expert Opin. Emerging Drugs 2009, DOI: 10.1517/14728210902907847.

[11] Ryan, S. M., Mantovani, G., Wang, X., Haddleton, D. M. et al., Advances in PEGylation of important biotech molecules: delivery aspects. Expert Opin. Drug Deliv. $2008,5,371-383$

[12] Gebauer, M., Skerra, A., Engineered protein scaffolds as next-generation antibody therapeutics. Curr. Opin. Chem. Biol. 2009, 13, 245-255.

[13] Nuttall, S. D., Walsh, R. B., Display scaffolds: protein engineering for novel therapeutics. Curr. Opin. Pharmacol. 2008, 8, 609-615.

[14] Skerra, A., Alternative non-antibody scaffolds for molecular recognition. Curr. Opin. Biotechnol. 2007, 18, 295-304.

[15] Harmsen, M. M., De Haard, H. J., Properties, production, and applications of camelid single-domain antibody fragments. Appl. Microbiol. Biotechnol. 2007, 77, 13-22.

[16] Wesolowski, J., Alzogaray, V., Reyelt, J., Unger, M. et al., Single domain antibodies: promising experimental and therapeutic tools in infection and immunity. Med. Microbiol. Immunol. 2009, 198, 157-174.

[17] Fishburn, C. S., The pharmacology of PEGylation: balancing PD with PK to generate novel therapeutics. J. Pharm. Sci. 2007. , DOI: 10.1002/jps.21278. 
[18] Hamidi, M., Rafiei, P., Azadi, A., Designing PEGylated therapeutic molecules: advantages in ADMET properties. Expert Opin. Drug Discov. 2008. DOI: 10.1517/17460441.3.11.1293.

[19] Veronese, F. M., Caliceti, P., Schiavon, O., Branched and Linear Poly(Ethylene Glycol): Influence of the Polymer Structure on Enzymological, Pharmacokinetic, and Immunological Properties of Protein Conjugates. J. Bioact. Compatible. Polym. 1997, DOI: $10.1177 / 088391159701200303$.

[20] Kawai, F., Microbial degradation of polyethers. Appl. Microbiol. Biotechnol. 2002, $58,30-38$

[21] Mehvar, R., Modulation of the pharmacokinetics and pharmacodynamics of proteins by polyethylene glycol conjugation. J. Pharm. Pharm. Sci. 2000, 3, 125-136.

[22] Beranova, M., Wasserbauer, R., Vancurova, D., Stifter, M. et al., Effect of cytochrome P-450 inhibition and stimulation on intensity of polyethylene degradation in microsomal fraction of mouse and rat livers. Biomaterials 1990, 11, 521-524.

[23] Caliceti, P., Veronese, F. M., Pharmacokinetic and biodistribution properties of poly(ethylene glycol)-protein conjugates. Adv. Drug Deliv. Rev. 2003, 55, 1261-1277. [24] Pasut, G., Veronese, F. M., Polymer-drug conjugation, recent achievements and general strategies . Prog. Polym. Sci. 2007 DOI: 10.1016/j.progpolymsci.2007.05.008.

[25] Filpula, D., Zhao, H., Releasable PEGylation of proteins with customized linkers. Adv. Drug Deliv. Rev. 2008, 60, 29-49.

[26] Basu, A., Yang, K., Wang, M., Liu, S. et al., Structure-function engineering of interferon-beta-1b for improving stability, solubility, potency, immunogenicity, and 
pharmacokinetic properties by site-selective mono-PEGylation. Bioconjug. Chem. 2006, 17, 618-630.

[27] Bailon, P., Palleroni, A., Schaffer, C. A., Spence, C. L. et al., Rational design of a potent, long-lasting form of interferon: a $40 \mathrm{kDa}$ branched polyethylene glycol-conjugated interferon alpha-2a for the treatment of hepatitis C. Bioconjug. Chem. 2001, 12, 195-202.

[28] Sehon, A. H., Suppression of antibody responses by conjugates of antigens and monomethoxypoly(ethylene glycol). Adv. Drug Deliv. Rev. 1991, DOI: 10.1016/0169409X(91)90041-A.

[29] Ganson, N. J., Kelly, S. J., Scarlett, E., Sundy, J. S. et al., Control of hyperuricemia in subjects with refractory gout, and induction of antibody against poly(ethylene glycol) (PEG), in a phase I trial of subcutaneous PEGylated urate oxidase. Arthritis Res. Ther. 2006, 8, R12.

[30] Judge, A., McClintock, K., Phelps, J. R., MacLachlan, I., Hypersensitivity and loss of disease site targeting caused by antibody responses to PEGylated liposomes. Mol. Ther. 2006, 13, 328-337.

[31] Wang, X., Ishida, T., Kiwada, H., Anti-PEG IgM elicited by injection of liposomes is involved in the enhanced blood clearance of a subsequent dose of PEGylated liposomes. J. Control Release 2007, 119, 236-244.

[32] Cheng, T. L., Chen, B. M., Chern, J. W., Wu, M. F. et al., Efficient clearance of poly(ethylene glycol)-modified immunoenzyme with anti-PEG monoclonal antibody for prodrug cancer therapy. Bioconjug. Chem. 2000, 11, 258-266. 
[33] Hamad, I., Hunter, A. C., Szebeni, J., Moghimi, S. M., Poly(ethylene glycol)s generate complement activation products in human serum through increased alternative pathway turnover and a MASP-2-dependent process. Mol. Immunol. 2008, 46, 225-232.

[34] Bendele, A., Seely, J., Richey, C., Sennello, G. et al., Short communication: renal tubular vacuolation in animals treated with polyethylene-glycol-conjugated proteins. Toxicol. Sci 1998, 42, 152-157.

[35] Caliceti, P., Schiavon, O., Veronese, F. M., Immunological properties of uricase conjugated to neutral soluble polymers. Bioconjug. Chem. 2001, 12, 515-522.

[36] Richter, A. W., Akerblom, E., Antibodies against polyethylene glycol produced in animals by immunization with monomethoxy polyethylene glycol modified proteins. Int. Arch. Allergy Appl. Immunol. 1983, 70, 124-131.

[37] Roberts, M. J., Bentley, M. D., Harris, J. M., Chemistry for peptide and protein PEGylation. Adv. Drug Deliv. Rev. 2002, 54, 459-476.

[38] Harris, J. M., Chess, R. B., Effect of pegylation on pharmaceuticals. Nat. Rev. Drug Discov. 2003, 2, 214-221.

[39] Bukowski, R., Ernstoff, M. S., Gore, M. E., Nemunaitis, J. J. et al., Pegylated interferon alfa-2b treatment for patients with solid tumors: a phase I/II study. J. Clin. Oncol. 2002, 20, 3841-3849.

[40] Gregoriadis, G., Jain, S., Papaioannou, I., Laing, P., Improving the therapeutic efficacy of peptides and proteins: a role for polysialic acids. Int. J. Pharm. 2005, 300, 125130. 
[41] Abuchowski, A., Kazo, G. M., Verhoest, C. R., Jr., Van, E. T. et al., Cancer therapy with chemically modified enzymes. I. Antitumor properties of polyethylene glycolasparaginase conjugates. Cancer Biochem. Biophys. 1984, 7, 175-186.

[42] Zalipsky, S., Seltzer, R., Menon-Rudolph, S., Evaluation of a new reagent for covalent attachment of polyethylene glycol to proteins. Biotechnol. Appl. Biochem. 1992, 15, 100114.

[43] Zalipsky, S., Seltzer, R., Nho, K., Succinimidyl Carbonates of Polyethylene Glycol in Dunn, R. L., Ottenbrite, R. M. (Ed.), Polymeric Drugs and Drug Delivery Systems, American Chemical Society, Wasington, DC 1991.

[44] Kinstler, O., Molineux, G., Treuheit, M., Ladd, D. et al., Mono-N-terminal poly(ethylene glycol)-protein conjugates. Adv. Drug Deliv. Rev. 2002, 54, 477-485.

[45] Molineux, G., The design and development of pegfilgrastim (PEG-rmetHuG-CSF, Neulasta). Curr. Pharm. Des. 2004, 10, 1235-1244.

[46] Veronese, F. M., Mero, A., Caboi, F., Sergi, M. et al., Site-specific pegylation of GCSF by reversible denaturation. Bioconjug. Chem. 2007, 18, 1824-1830.

[47] Doherty, D. H., Rosendahl, M. S., Smith, D. J., Hughes, J. M. et al., Site-specific PEGylation of engineered cysteine analogues of recombinant human granulocytemacrophage colony-stimulating factor. Bioconjug. Chem. 2005, 16, 1291-1298.

[48] Rosendahl, M. S., Doherty, D. H., Smith, D. J., Carlson, S. J. et al., A long-acting, highly potent interferon alpha-2 conjugate created using site-specific PEGylation. Bioconjug. Chem. 2005, 16, 200-207. 
[49] Humphreys, D. P., Heywood, S. P., Henry, A., Ait-Lhadj, L. et al., Alternative antibody Fab' fragment PEGylation strategies: combination of strong reducing agents, disruption of the interchain disulphide bond and disulphide engineering. Protein Eng Des Sel. 2007, 20, 227-234.

[50] Balan, S., Choi, J. W., Godwin, A., Teo, I. et al., Site-specific PEGylation of protein disulfide bonds using a three-carbon bridge. Bioconjug. Chem. 2007, 18, 61-76.

[51] Shaunak, S., Godwin, A., Choi, J. W., Balan, S. et al., Site-specific PEGylation of native disulfide bonds in therapeutic proteins. Nat. Chem. Biol. 2006, 2, 312-313.

[52] Deiters, A., Schultz, P. G., In vivo incorporation of an alkyne into proteins in Escherichia coli. Bioorg. Med. Chem. Lett. 2005, 15, 1521-1524.

[53] Sato, H., Enzymatic procedure for site-specific pegylation of proteins. Adv. Drug Deliv. Rev. 2002, 54, 487-504.

[54] Fontana, A., Spolaore, B., Mero, A., Veronese, F. M., Site-specific modification and PEGylation of pharmaceutical proteins mediated by transglutaminase. Adv. Drug Deliv. Rev. 2008, 60, 13-28.

[55] DeFrees, S., Wang, Z. G., Xing, R., Scott, A. E. et al., GlycoPEGylation of recombinant therapeutic proteins produced in Escherichia coli. Glycobiology 2006, 16, 833843.

[56] Fee, C. J., Van Alstine, J. M., PEG-proteins: Reaction engineering and separation issues. Chem Eng Sci. 2006, 61, 924-939.

[57] Kusterle, M., Jevsevar, S., Porekar, V. G., Size of Pegylated Protein Conjugates Studied by Various Methods. Acta Chim Sloven. 2008, 55, 594-601. 
[58] Fee, C. J., Size comparison between proteins PEGylated with branched and linear Poly(Ethylene glycol) molecules. Biotechnol. Bioeng. 2007, 98, 725-731.

[59] Seely, J. E., Richey, C. W., Use of ion-exchange chromatography and hydrophobic interaction chromatography in the preparation and recovery of polyethylene glycol-linked proteins. J. Chromatogr. A 2001, 908, 235-241.

[60] Seely, J. E., Buckel, S. D., Green, P. D., Richey, C. W., Making site-specific PEGylation work. Biopharm International 2005,.

[61] Caserman, S., Kusterle, M., Kunstelj, M., Milunovic, T. et al., Correlations between in vitro potency of polyethylene glycol-protein conjugates and their chromatographic behavior. Anal. Biochem. 2009, 389, 27-31.

[62] Chapman, A. P., Antoniw, P., Spitali, M., West, S. et al., Therapeutic antibody fragments with prolonged in vivo half-lives. Nat. Biotechnol. 1999, 17, 780-783.

[63] Foser, S., Schacher, A., Weyer, K. A., Brugger, D. et al., Isolation, structural characterization, and antiviral activity of positional isomers of monopegylated interferon alpha-2a (PEGASYS). Protein Expr. Purif. 2003, 30, 78-87.

[64] Yun, Q., Yang, R. E., Chen, T., Bi, J. et al., Reproducible preparation and effective separation of PEGylated recombinant human granulocyte colony-stimulating factor with novel "PEG-pellet" PEGylation mode and ion-exchange chromatography. J. Biotech. 2005. DOI: 10.1016/j.jbiotec.2005.02.015.

[65] Pabst, T. M., Buckley, J. J., Ramasubramanyan, N., Hunter, A. K., Comparison of strong anion-exchangers for the purification of a PEGylated protein. J. Chromatogr. A 2007, 1147, 172-182. 
[66] Edwards, C. K., III, Martin, S. W., Seely, J., Kinstler, O. et al., Design of PEGylated soluble tumor necrosis factor receptor type I (PEG sTNF-RI) for chronic inflammatory diseases. Adv. Drug Deliv. Rev. 2003, 55, 1315-1336.

[67] Molek, J. R., Zydney, A. L., Ultrafiltration characteristics of pegylated proteins. Biotechnol. Bioeng. 2006, 95, 474-482.

[68] Kou, D., Manius, G., Zhan, S., Chokshi, H. P., Size exclusion chromatography with Corona charged aerosol detector for the analysis of polyethylene glycol polymer. J.

Chromatogr. A 2009, 1216, 5424-5428.

[69] Montaudo, G., Samperi, F., Montaudo, M. S., Characterization of synthetic polymers by MALDI-MS . Prog. Polym. Sci. 2006, DOI: 10.1016/j.progpolymsci.2005.12.001.

[70] Fee, C. J., Van Alstine, J. M., Prediction of the viscosity radius and the size exclusion chromatography behavior of PEGylated proteins. Bioconjug. Chem. 2004, 15, 1304-1313.

[71] Gaberc-Porekar, V., Zore, I., Podobnik, B., Menart, V., Obstacles and pitfalls in the PEGylation of therapeutic proteins. Curr. Opin. Drug Discov. Devel. 2008, 11, 242-250.

[72] Piedmonte, D. M., Treuheit, M. J., Formulation of Neulasta(R) (pegfilgrastim). Adv. Drug Deliv. Rev. 2008, 60, 50-58.

[73] Kurfurst, M. M., Detection and Molecular-Weight Determination of Polyethylene Glycol-Modified Hirudin by Staining After Sodium Dodecyl-Sulfate Polyacrylamide-Gel Electrophoresis. Anal. Biochem. 1992, 200, 244-248.

[74] Wang, Y. S., Youngster, S., Grace, M., Bausch, J. et al., Structural and biological characterization of pegylated recombinant interferon alpha- $2 b$ and its therapeutic implications. Adv. Drug Deliv. Rev. 2002, 54, 547-570. 
[75] Srebalus Barnes, C. A., Lim, A., Applications of mass spectrometry for the structural characterization of recombinant protein pharmaceuticals. Mass Spectrom. Rev. 2007, 26, $370-388$.

[76] Cindric, M., Cepo, T., Galic, N., Bukvic-Krajacic, M. et al., Structural characterization of PEGylated rHuG-CSF and location of PEG attachment sites. J. Pharm. Biomed. Anal. 2007, 44, 388-395.

[77] Mero, A., Spolaore, B., Veronese, F. M., Fontana, A., Transglutaminase-mediated PEGylation of proteins: Direct identification of the sites of protein modification by mass spectrometry using a novel monodisperse PEG. Bioconjugate Chem. 2009, 20, 384-389.

[78] Mahmood, I., Green, M. D., Pharmacokinetic and pharmacodynamic considerations in the development of therapeutic proteins. Clin. Pharmacokinet. 2005, 44, 331-347.

[79] Roovers, R. C., van Dongen, G. A., van Bergen en Henegouwen PM, Nanobodies in therapeutic applications. Curr. Opin. Mol. Ther. 2007, 9, 327-335. 


\section{Figure legends}

Figure 1: Influence of the molecular weight (Mw) of N-terminally PEGylated IFNalpha $\alpha-2 b$ conjugates (bearing linear $10 \mathrm{kDa}, 20 \mathrm{kDa}, 30 \mathrm{kDa}$ and branched $45 \mathrm{kDa}$ PEGs) on their in vitro potency determined by reporter gene assay assay [45] and elimination half life in rats after i.v. administration.

Figure 2: SEC analysis of various types of molecules having a similar molecular mass of approximately $40 \mathrm{kDa}: 40 \mathrm{kDa}$ branched PEG-CHO reagent (derivatized with paminobenzoic acid to enable UV detection), IFNalpha of Mw $19 \mathrm{kDa}$ conjugated with $20 \mathrm{kDa}$ PEG-CHO reagent and ovalbumin with MW of $38 \mathrm{kDa}$.

Figure 3: Comparison of preparative CEX separations of IFNalpha pegylation mixtures prepared with various mPEG-CHO reagents of different lengths and shapes (20 kDa linear, $30 \mathrm{kDa}$ linear and $45 \mathrm{kDa}$ branched) on TSK-gel SP-5PW column (Tosoh Bioscience, Japan). Peak 1 designates higher-PEGylated IFNalpha forms, 2 mono-PEGylated IFNalpha forms and 3 un-PEGylated IFNalpha. 
Table 1: Overview of PEGylation technologies currently used

\begin{tabular}{|c|c|c|c|c|c|c|c|}
\hline \multirow[t]{2}{*}{ Attachment site } & \multirow[t]{2}{*}{ PEG Reagent } & \multirow[t]{2}{*}{ Applicable for } & \multicolumn{4}{|c|}{ Development status } & \multirow[t]{2}{*}{ Marketed drug (Active substance) } \\
\hline & & & Research & $\begin{array}{l}\text { Pre- } \\
\text { clinic }\end{array}$ & Clinic & Market & \\
\hline \multicolumn{8}{|c|}{ Random PEGylations } \\
\hline $\begin{array}{l}\text { Predominantly } \varepsilon \text { amino } \\
\text { groups of Lysine } \\
\text { residues and } \mathrm{N} \text {-terminal } \\
\text { amino groups }\end{array}$ & $\begin{array}{l}\text { PEG NHS-esters, } \\
\text { PEG NHS-carbonates, } \\
\text { PEG-p-nitrophenyl } \\
\text { carbonates, } \\
\text { PEG-triazine reagents, } \\
\text { etc. }\end{array}$ & All proteins & $\sqrt{ }$ & $\sqrt{ }$ & $\sqrt{ }$ & $\sqrt{ }$ & $\begin{array}{l}\text { Adagen }{ }^{\circledR}(\text { Adenosin deaminase) } \\
\text { Oncaspar }{ }^{\circledR} \text { (Asparaginase) } \\
\left.\text { PegIntron }{ }^{\circledR} \text { (Interferon- } \alpha 2 b\right) \\
\text { Pegasys }{ }^{\circledR}(\text { Interferon- } \alpha 2 a) \\
\text { Somavert }{ }^{\circledR} \text { (Human growth hormon mutein) } \\
\text { Mircera }{ }^{\circledR} \text { (Erythropoietin) }\end{array}$ \\
\hline \multicolumn{8}{|c|}{ Site-specific PEGylations (Chemical) } \\
\hline N-terminal amino group & $\begin{array}{l}\text { PEG-aldehydes and } \\
\text { reducing agent }\end{array}$ & All proteins & $\sqrt{ }$ & $\sqrt{ }$ & $\sqrt{ }$ & $\sqrt{ }$ & Neulasta ${ }^{\circledR}(\mathrm{G}-\mathrm{CSF})$ \\
\hline $\begin{array}{l}\text {-SH group of unpaired } \\
\text { cysteine residues }\end{array}$ & $\begin{array}{l}\text { PEG-maleimides } \\
\text { Pyridyl disulfides } \\
\text { Vinyl sulfones } \\
\text { Thiol reagents } \\
\end{array}$ & $\begin{array}{l}\text { Proteins with natural or } \\
\text { engineered surface Cys } \\
\text { residues }\end{array}$ & $\sqrt{ }$ & $\sqrt{ }$ & $\sqrt{ }$ & $\sqrt{ }$ & Cimzia ${ }^{\circledR}($ Anti-TNF- $\alpha$ Fab') \\
\hline $\begin{array}{l}\text { Non-natural amino acids } \\
\text { (azido and ethynyl } \\
\text { derivatives of serine) }\end{array}$ & $\begin{array}{l}\text { PEG-ethynyl reagents } \\
\text { PEG-azido reagents }\end{array}$ & $\begin{array}{l}\text { Proteins with non-natural } \\
\text { amino acids - (genetic } \\
\text { manipulation of the host } \\
\text { organism needed) }\end{array}$ & $\sqrt{ }$ & $\sqrt{ }$ & $\sqrt{ }$ & & 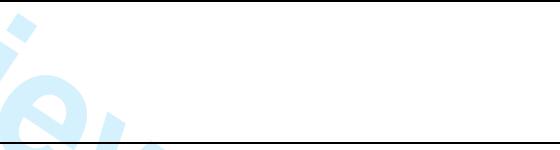 \\
\hline Disulfide bond & PEG monosulfones & $\begin{array}{l}\text { Proteins with surface }-S- \\
\text { S- bonds }\end{array}$ & $\sqrt{ }$ & $\sqrt{ }$ & $?$ & & 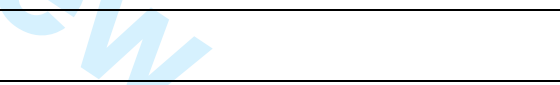 \\
\hline Histidine affinity tag & PEG sulfones & $\begin{array}{l}\text { Engineered His-tagged } \\
\text { proteins }\end{array}$ & $\sqrt{ }$ & & & & 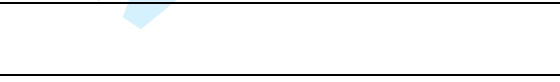 \\
\hline
\end{tabular}




\section{Page 41 of 50}

Biotechnology Journal

\begin{tabular}{|l|l|l|l|l|l|l|l|}
\hline Serine or Threonine & $\begin{array}{l}\text { N-actylgalactosamine and } \\
\text { PEG-sialic acid } \\
\text { derivatives (O-GalNAc- } \\
\text { transferase and } \\
\text { sialyltransferase } \\
\text { mediated) }\end{array}$ & $\begin{array}{l}\text { Non-glycosylated } \\
\text { proteins with exposed Ser } \\
\text { or Thr residues }\end{array}$ & $\sqrt{ }$ & $\sqrt{ }$ & $\sqrt{ }$ & & \\
\hline Glutamine residues & $\begin{array}{l}\text { PEG-alkylamines } \\
\text { (Transglutaminase } \\
\text { mediated) }\end{array}$ & $\begin{array}{l}\text { Proteins with natural or } \\
\text { engineered Gn residues } \\
\text { in flexible regions }\end{array}$ & $\sqrt{ }$ & & & \\
\hline
\end{tabular}

Formatted: Left, Level 1, Line spacing: single, Keep with next 
Table 2: Marketed PEGylated biopharmaceuticals

\begin{tabular}{|c|c|c|c|c|c|}
\hline$\underline{\text { Name }}$ & Company & Original protein & Therapeutic indication & Engineering rationale & $\frac{\text { Year to }}{\text { market }}$ \\
\hline Adagen & Enzon & $\begin{array}{l}\text { Bovine Adenosine } \\
\text { Deamidase }\end{array}$ & $\frac{\text { Severe combined }}{\text { immunodefficiency (SCID) }}$ & $\underline{\text { Increased serum half-life }}$ & $\underline{\underline{1990}}$ \\
\hline $\begin{array}{l}\text { Oncaspar }{ }^{\circledR} \\
\text { (Pegaspargase) }\end{array}$ & $\underline{\text { Enzon }}$ & Asparaginase & Acute lymphoblastic leukemia & $\begin{array}{l}\underline{\text { Increased serum half-life, }} \\
\text { less alergic reactions }\end{array}$ & $\underline{1994}$ \\
\hline $\begin{array}{l}\text { PEG-Intron }{ }^{\circledR} \\
\text { (PEGylated IFN- } \alpha 2 b) \\
\end{array}$ & $\underline{\text { Schering-Plough / Enzon }}$ & IFN- $\alpha 2 b$ & Hepatitis C & Increased serum half-life & 2001 \\
\hline$\frac{\text { Pegasys } ®}{(\text { PEGylated IFN- } \alpha 2 \mathrm{a})}$ & $\underline{\text { Hoffmann-La Roche }}$ & IFN- $\alpha 2 \mathrm{a}$ & Hepatitis C & Increased serum half-life & $\underline{2002}$ \\
\hline $\begin{array}{l}\text { Neulasta }{ }^{\circledR} \\
\text { (pegfilgrastim) }\end{array}$ & Amgen / Nektar & G-CSF & Neutropenia & $\underline{\text { Increased serum half-life }}$ & 2002 \\
\hline Somavert ${ }^{\circledR}$ (Pegvisomant) & $\underline{\text { Pfizer / Nektar }}$ & $\underline{\text { hGH mutein }}$ & Acromegaly & hGH-receptor antagonist & 2003 \\
\hline $\begin{array}{l}\text { MIRCERA } ® \\
\text { PEGylated epoetin- } \beta\end{array}$ & Hoffmann-La Roche & epoetin- $\beta$ & $\begin{array}{l}\text { anemia associated with } \\
\text { chronic renal failure }\end{array}$ & $\underline{\text { Increased serum half-life }}$ & $\underline{2007}$ \\
\hline $\begin{array}{l}\text { Certolizumab pegol } \\
\text { (Cimzia) }\end{array}$ & $\underline{\mathrm{UCB}}$ & $\underline{\text { anti TNF Fab }}$ & $\begin{array}{l}\text { Reumatoid arthritis and } \\
\text { Crohn's disease }\end{array}$ & $\underline{\text { Increased serum half-life }}$ & $\underline{2008}$ \\
\hline $\begin{array}{l}\text { Macugen }(\text { or } \text { Macuverse } \AA \text { (1) } \\
\text { (pegaptanib) }\end{array}$ & $\underline{\text { Pfizer }}$ & $\begin{array}{l}\underline{\text { anti-VEGF }} \\
\text { aptamer (an RNA } \\
\text { oligonucleotide) }\end{array}$ & $\begin{array}{l}\text { treatment of ocular vascular } \\
\text { disease }\end{array}$ & - & 2004 \\
\hline
\end{tabular}


Simona Jevševar studied Biochemical Engineering at the University of Ljubljana and received her $\mathrm{PhD}$ in Biotechnology. She joined Lek Pharmaceuticals d.d. in 1996 and started her career as a researcher in development of technology for production of E. coli derived biosimilars. Since 2004, after Lek merged to Novartis, she has been working in the field of posttranslational protein modification by PEGylation. Since February 2007 she hold position of a Group Leader in Next Generation Proteins Department within Technical Development of Biopharmaceuticals Operations Menges (Lek d.d., a Sandoz company) which is one of 6 Biopharmaceuticals Operations' sites within Novartis. She is responsible for all aspects of technical development of PEGylated products starting from early development to late development phases. Projects include Sandoz biosimilar and Novartis innovative pipeline. Additionally she is responsible for some contract collaboration between Lek d.d. and academic environment in Slovenia. 


\section{Fig 1}

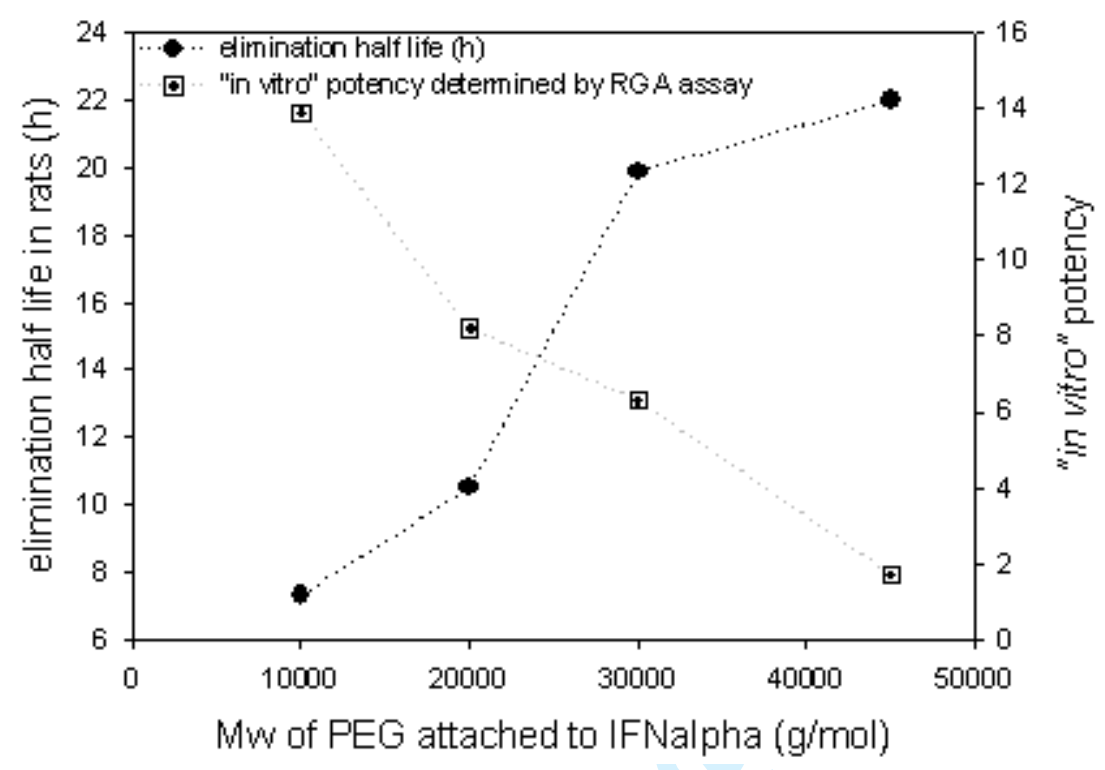

Fig 2 


1
2
3
4
5
6
7
8
9
10
11
12
13
14
15
16
17
18
19
20
21
22
23
24
25
26
27
28
29
30
31
32
33
34
35
36
37
38
39
40
41
42
43
44
45
46
47
50
58
59
50
52
53
50

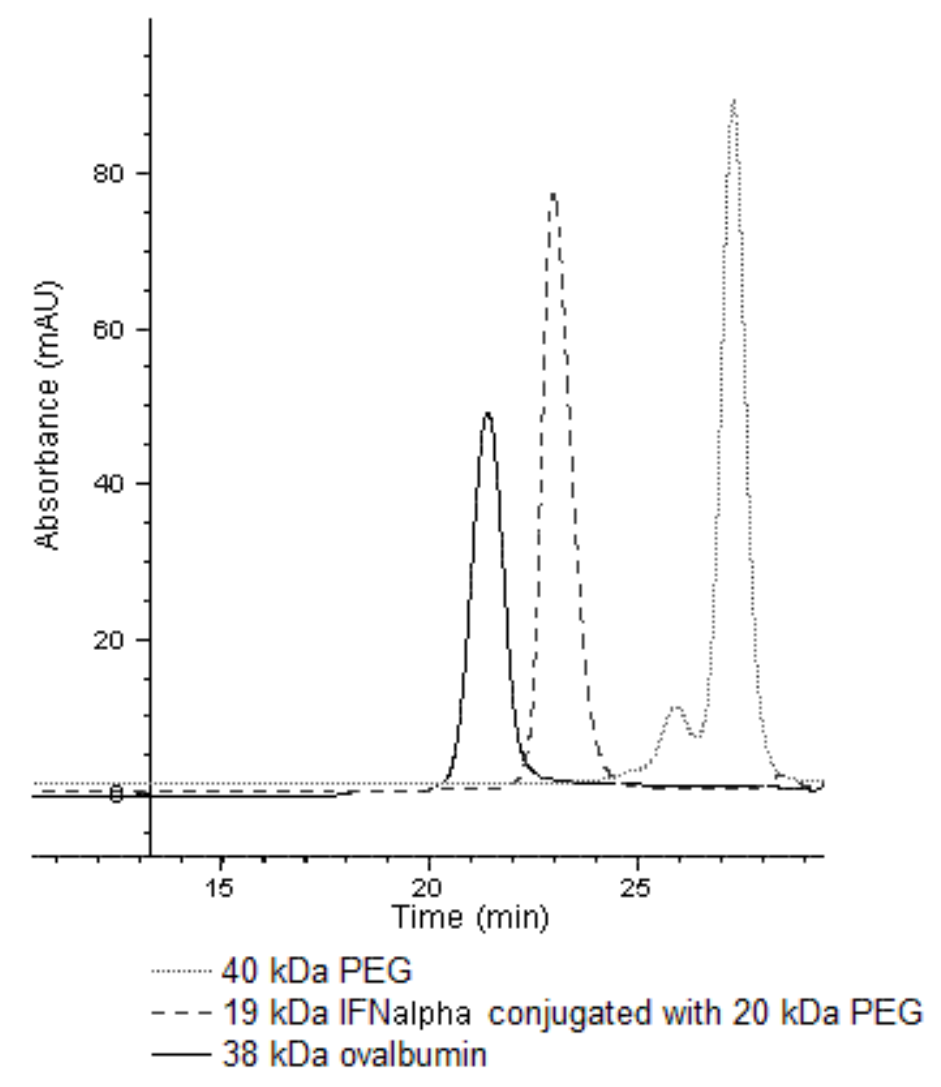

Fig 3

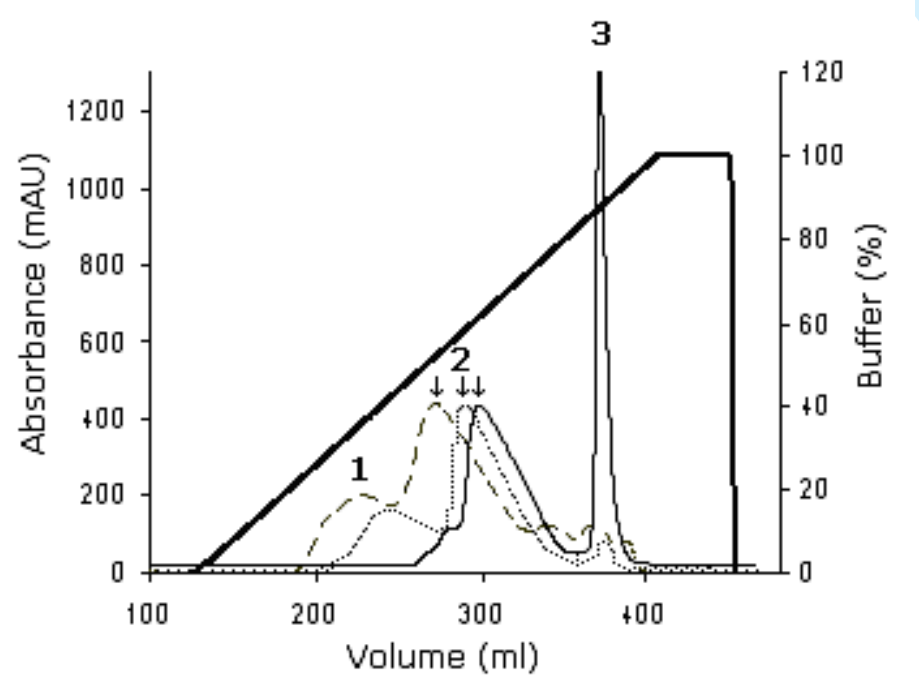

— IFNalpha conjugated with $20 \mathrm{kDa}$ PEG-CHO

........ IFNalpha conjugated with $30 \mathrm{kDa} P E G-\mathrm{CHO}$

- - - - IFNalpha conjugated with $45 \mathrm{kDa}$ PEG-CHO 


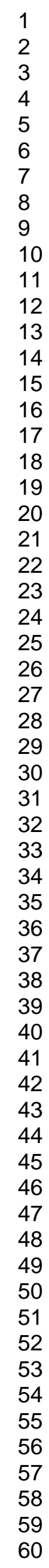


((biot.200900218-figures))

Fig 1

Deleted:

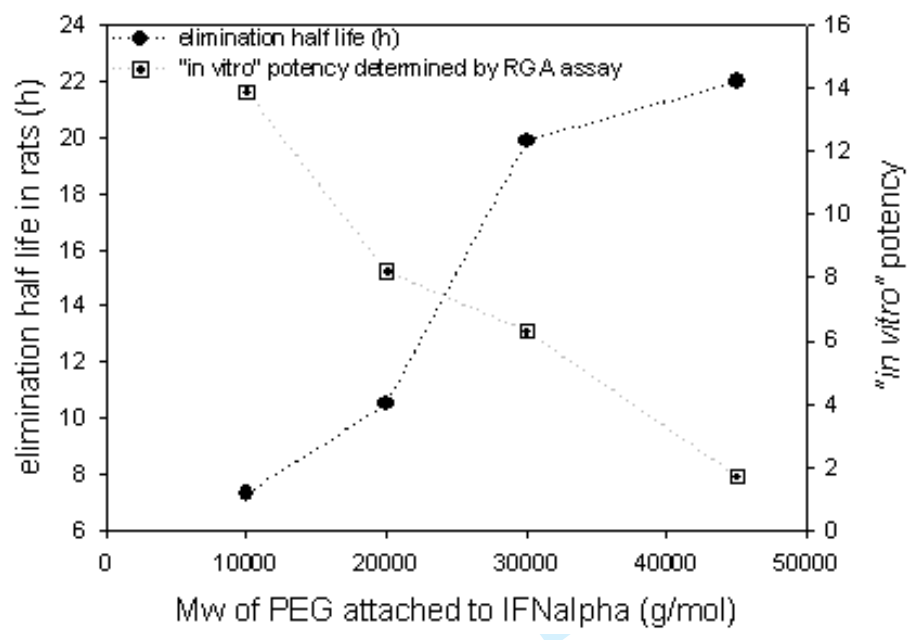

25

26

27

28

29

30

31

32

33

34

35

36

37

38

39

40

41

42

43

44

45

46

47

48

49

50

51

52

53

54

55

56

57

58

59 
| Fig 2

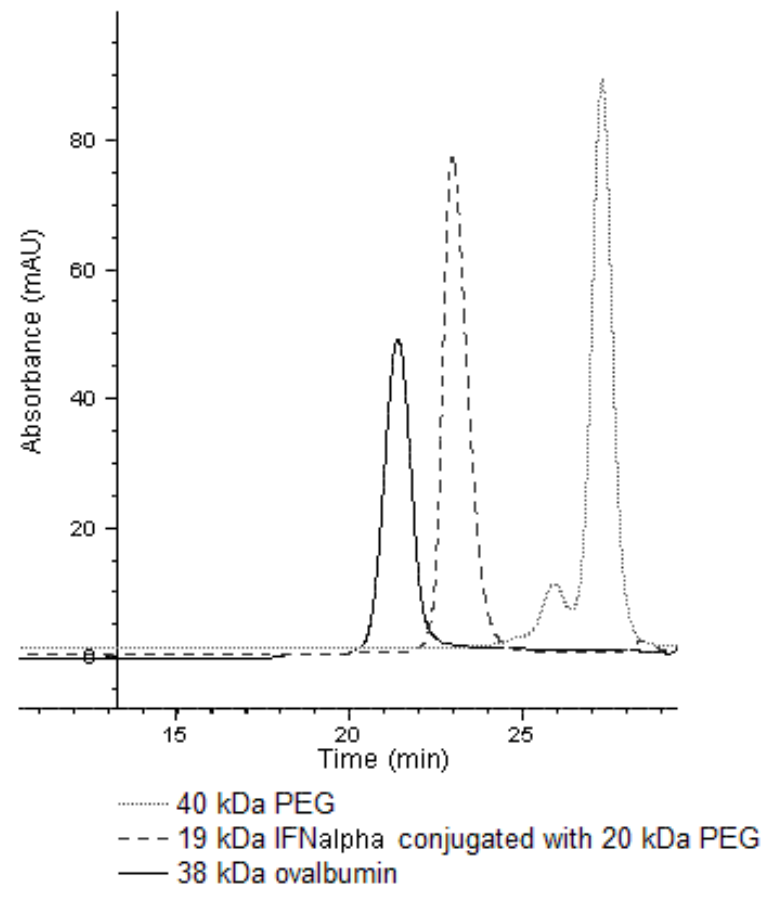

Deleted: Fig 2q

II

Deleted: 3 
Fig 3

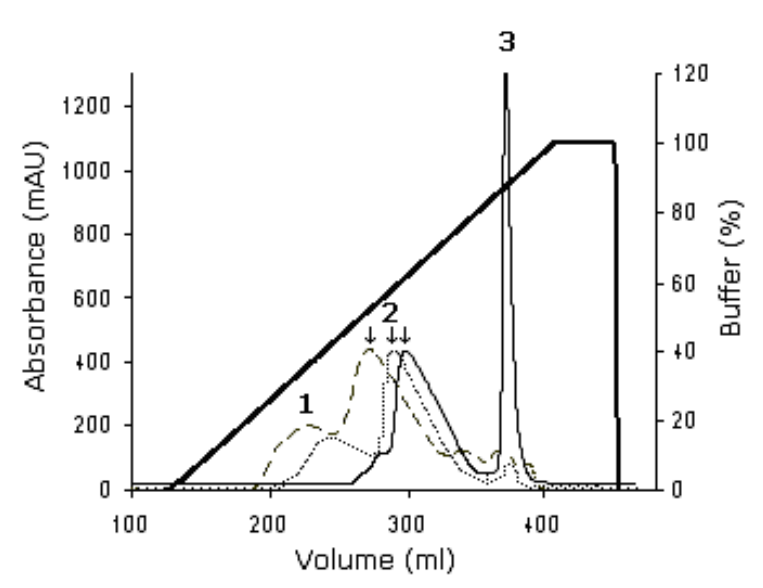

- IFNalpha conjugated with $20 \mathrm{kDa}$ PEG-CHO

........... IFNalpha conjugated with $30 \mathrm{kDa} P E G-\mathrm{CHO}$

- - - - IFNalpha conjugated with $45 \mathrm{kDa}$ PEG-CHO 


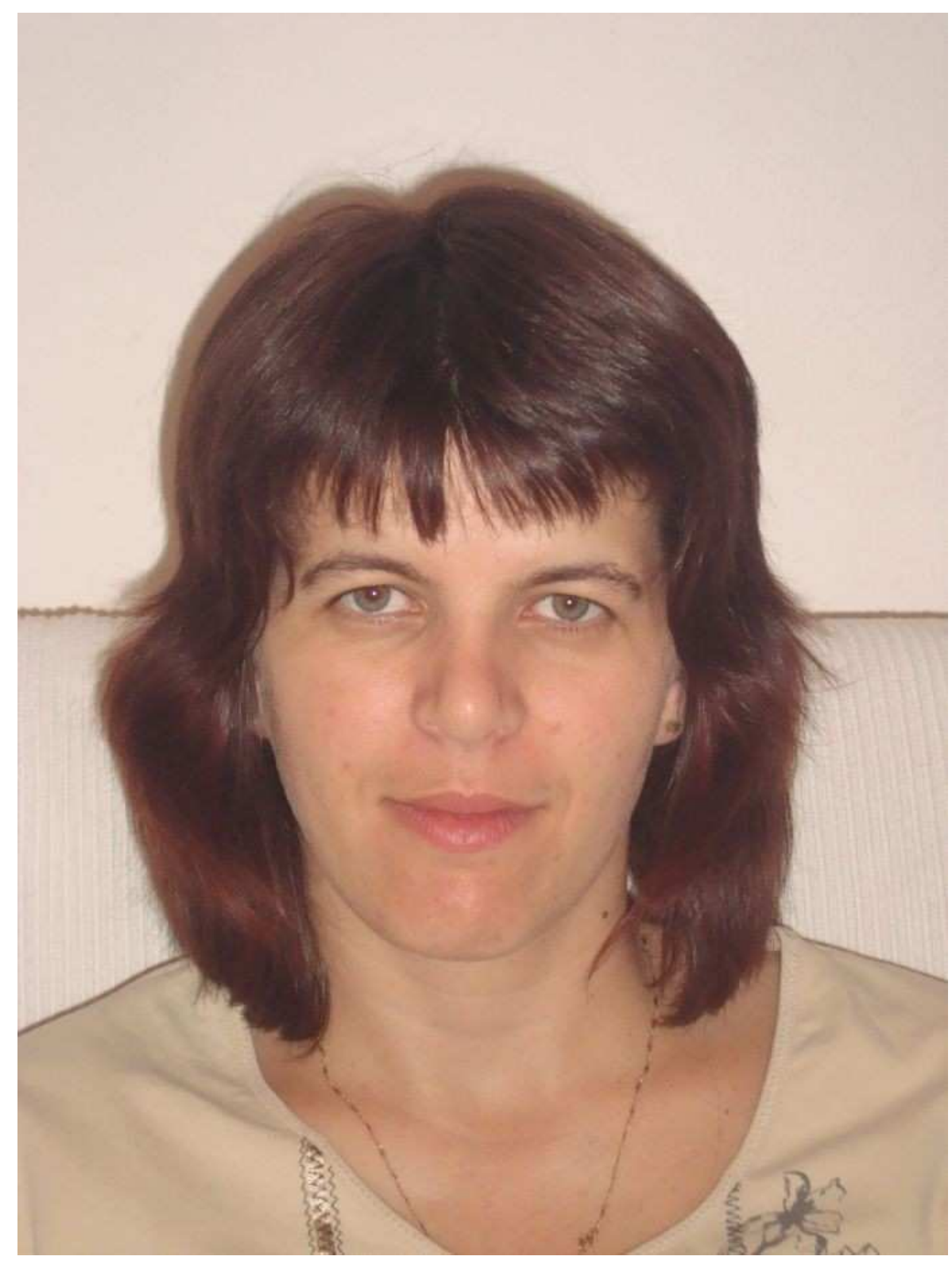

$182 \times 243 \mathrm{~mm}(96 \times 96 \mathrm{DPI})$

Wiley-VCH 